\title{
DESAIN FASILITAS PENGADUK PAKAN TERNAK UNTUK PENINGKATAN PRODUKSI SUSU
}

\author{
Sanny Andjar Sari \\ Staf Pengajar Program Studi Teknik Industri, Institut Teknologi Nasional, Malang \\ e-mail: sannysari@yahoo.com \\ Dayal Gustopo \\ Staf Pengajar Program Studi Teknik Industri, Institut Teknologi Nasional, Malang
}

\begin{abstract}
Efforts to improve the quality of the results of milking cow's milk can not be separated from the quality of feed for cattle. Dairy farm in dire need of high-quality cattle feed. However, to support the fulfillment of a good cow feed mixer also needed a good feed anyway. On farms in the area Pujon, Batu Malang, there are activities that are less efficient, in terms of time and energy. One was in the process of mixing the feed are still using manual equipment, bending operator position in a long time, and the results are not in accordance with the composition of mortar required.

This study focuses on the means for stirring fodder with application of ergonomics. The first stage is to calculate working time data feed stirring with manual tools for standard time and standard output, as well as calculate the anthropometric data. The position of the operator is established, then the anthropometric data are used for animal feed mixer include high elbow in a standing position, stretch the hand and arm's reach to the side. The second stage is to make the design as per calculation anthropometry and technical considerations to then make animal feed mixing machine. The last stage is to calculate working time data feed stirring with design tools to get the results of standard time and standard output.

Automatic feed mixing machine that is the dimension $143 \times 57 \times 109 \mathrm{~cm}^{3}$. Driving force used is 1-phase electric motor with a power of $1 \mathrm{HP}$. The results showed that the Standard Time (Wb) decreased by 0:17 $\mathrm{min} / \mathrm{kg}$ ie from the old tool (manual) 0:25 $\mathrm{min} / \mathrm{kg}$ to 0:08 $\mathrm{min} / \mathrm{kg}$ in tool design results, and increased output Standart (Os) of $8.5 \mathrm{~kg} / \mathrm{min}$ with percentage of $212.5 \%$ from $4 \mathrm{~kg} / \mathrm{min}$ to $12.5 \mathrm{~kg} / \mathrm{min}$.
\end{abstract}

Key words: Design, Facilities, Mixer Feed 
Abstrak

Upaya meningkatkan kualitas susu hasil perahan sapi tidak terlepas dari mutu pakan bagi sapi. Peternakan sapi perah sangat membutuhkan pakan sapi yang berkualitas tinggi. Akan tetapi untuk mendukung terpenuhinya pakan sapi yang baik juga dibutuhkan alat pencampur pakan yang baik pula. Pada peternakan di daerah Pujon, Batu Malang ini, masih terdapat aktifitas kerja yang kurang efisien, ditinjau dari waktu dan tenaga. Salah satunya pada proses pengadukan pakan yang masih menggunakan peralatan manual, posisi operator membungkuk dalam waktu yang cukup lama, dan hasil adukan tidak sesuai dengan komposisi yang dibutuhkan.

Penelitian ini memfokuskan pada sarana untuk pengadukkan pakan ternak dengan penerapan ergonomi. Tahap pertama adalah menghitung data waktu kerja pengadukkan pakan dengan alat manual untuk mendapatkan waktu baku dan output standart, serta menghitung data antropometri .Posisi kerja operator adalah berdiri, maka data antropometri yang digunakan untuk pengaduk pakan ternak ini antara lain tinggi siku pada posisi berdiri, bentangan tangan dan jangkauan lengan ke samping. Tahap kedua adalah membuat desain sesuai perhitungan antropometri dan pertimbangan-pertimbangan teknis untuk kemudian membuat mesin pengaduk pakan ternak. Tahap terakhir adalah menghitung data waktu kerja pengadukkan pakan dengan alat hasil perancangan untuk mendapatkan waktu baku dan output standart.

Mesin pengaduk pakan ternak otomatis yaitu berdimensi 143 x 57 × $109 \mathrm{~cm}^{3}$. Tenaga penggerak yang dipakai adalah motor listrik 1 phasa dengan daya sebesar 1 HP. Hasil penelitian menunjukkan bahwa Waktu Baku (Wb) mengalami penurunan sebesar 0.17 menit/ $\mathrm{kg}$ yaitu dari alat lama (manual) 0.25 menit $/ \mathrm{kg}$ menjadi 0.08 menit $/ \mathrm{kg}$ pada alat hasil perancangan, dan peningkatan Output Standart (Os) sebesar $8.5 \mathrm{~kg} /$ menit dengan prosentase $212.5 \%$ yaitu dari $4 \mathrm{~kg} /$ menit menjadi $12.5 \mathrm{~kg} /$ menit.

Kata kunci: Desain ,Fasilitas, Pengaduk Pakan Ternak

\section{PENDAHULUAN}

Kualitas air susu dipengaruhi oleh makanan yang diberikan pada sapi, semakin tinggi nilai gizi yang diberikan semakin tinggi pula kualitas susu yang dihasilkan sapi tersebut. Makanan bagi sapi perah mengandung serat kasar yaitu rumput, daun-daunan, makanan penguat (konsentrat) yaitu makanan yang berserat kasar rendah sehingga mudah dicerna yang berfungsi sebagai gizi bagi sapi perah, misalnya: bungkil kelapa, jagung, kedelai, bungkil kacang, dan sebagainya. Selain itu sapi perah juga diberi makanan tambahan seperti vitamin dan mineral.

Di peternakan sapi perah di daerah Pujon, Batu Malang yang menjadi objek penelitian ini memiliki 250 ekor sapi. Dalam pemberian pakan dilakukan sebanyak
2 kali sehari, dimana dalam satu kali makan terdapat 3 jenis makanan. Jenis makanan pertama adalah rumput-rumputan, jenis kedua adalah makanan basah, dan jenis terakhir adalah makanan kering. Komponen pakan kering yang perlu dicampur terdiri dari dedak, polar, kulit kopi, bungkil (ampas kelapa) dan garam. Pencampuran (pengadukan) material-material pakan kering tersebut dilakukan 3 hari sekali. Komposisi setiap material yang diaduk tidak sama, yaitu: dedak $750 \mathrm{~kg}$, bungkil $250 \mathrm{~kg}$, polar $250 \mathrm{~kg}$, kulit kopi 250 kg, garam 35 kg. Total dari keseluruhan material yang harus dicampur adalah $1535 \mathrm{~kg}$, untuk tiga hari.

Dalam pengerjaan mempersiapkan material saat ini dilakukan oleh 6 pekerja yang memiliki tugas masing- 
Sanny Andjar Sari, Dayal Gustopo, Desain Fasilitas Pengaduk Pakan Ternak Untuk Peningkatan Produksi Susu

masing. Empat orang pekerja bertugas menuangkan material secara bertumpuk ke tempat penadahan. Dua orang pekerja bertugas menimbang dan mengangkut material dari gudang menuju tempat pengadukan. Sedangkan dalam proses pengadukan material dilakukan oleh satu orang pekerja dengan menggunakan cangkul. Waktu yang dibutuhkan untuk satu kali proses pengadukan selama 15 menit, dengan total material yang diaduk sebanyak 85,3 kg. Total waktu yang diperlukan dalam proses pengadukan ini adalah 75 menit, dari persiapan material sampai proses pengadukannya. Para pekerja hanya memperkirakan saja hasil pakan. Setelah tercampur, hasil adukan diambil dengan menggunakan timba. Proses pengadukan sangat melelahkan dan memerlukan waktu yang cukup lama. Dari hasil simulasi postur tubuh operator pengaduk pakan dengan menggunakan software Mannequin Pro diperoleh beban torsi pada punggung operator sebesar $82 \mathrm{Nm}$ dan pada leher sebesar $7 \mathrm{Nm}$, hal tersebut menjadikan proses pengadukan pakan menjadi melelahkan bagi operator seperti yang dapat dilihat pada tabel torsi di tabel 1

Dari tabel 1 tersebut dapat disimpulkan bahwa titik kelelahan tubuh yang paling tinggi dialami pada bagian punggung.

Proses manual seperti ini menyebabkan pengadukan menjadi tidak rata dan komposisi pembagian makanan yang tidak sesuai ukuran karena hanya menggunakan perkiraan saja. Jika pembagian komposisi pakan tidak sesuai (akibat pengadukan yang tidak merata), maka dapat mempengaruhi kualitas dan kuantitas susu.

Tabel 1. Beban Torsi Operator Menggunakan Fasilitas Lama

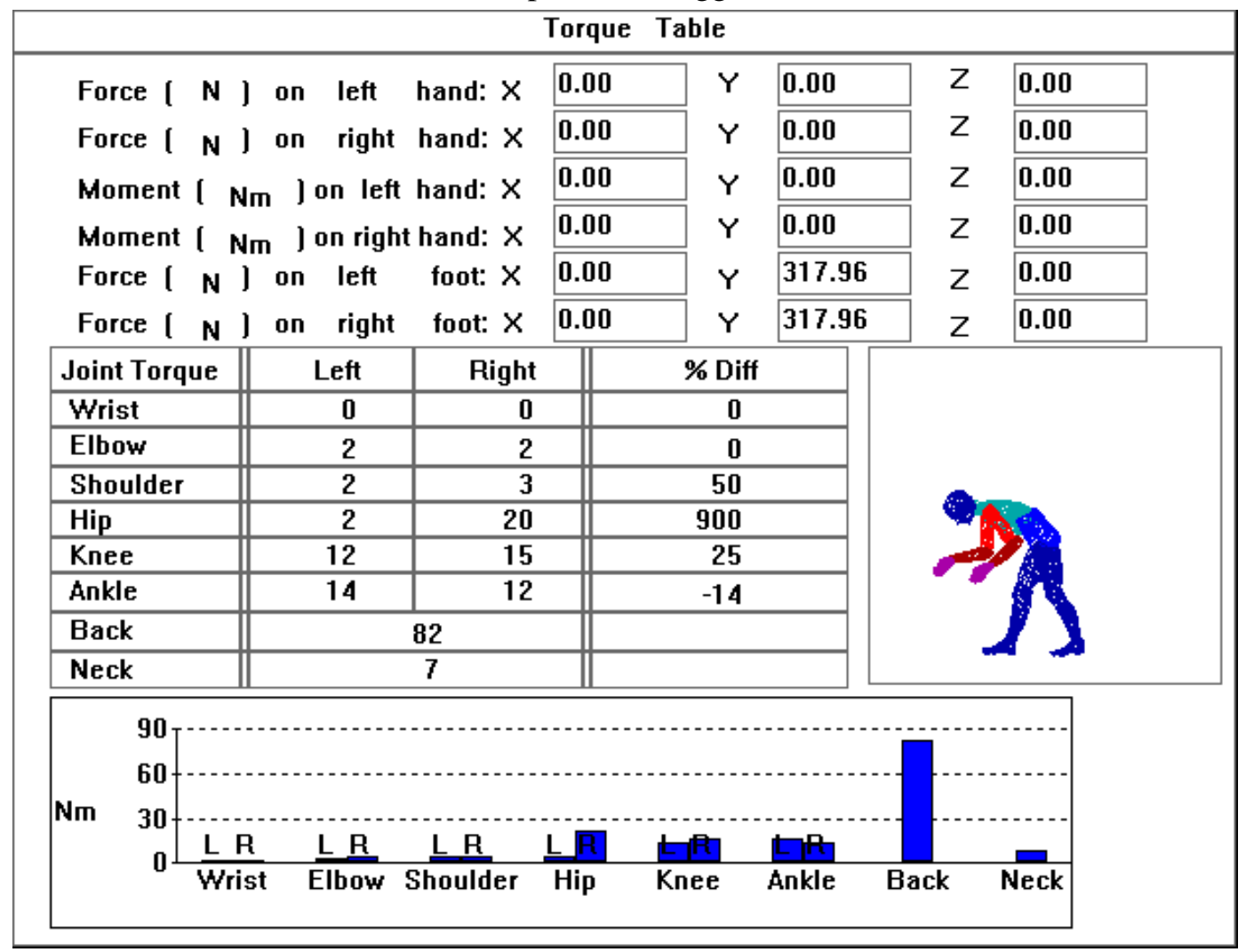

Sumber: Pengolahan data menggunakan software Mannequin Pro 
Vol. 2, No. 1, Oktober 2014

Sedangkan dari waktu proses pengerjaan pengadukan, dari hasil observasi awal diperoleh waktu baku proses pengadukan sebesar 18,74 menit untuk 85,3 kg.

Berdasarkan latar belakang yang dikemukakan diatas permasalahan yang dalam penelitian ini adalah : Bagaimana merancang dan membuat sebuah fasilitas pengaduk pakan ternak yang praktis dan efisien agar dapat mengoptimalkan waktu kerja.

Tujuan Perancangan:

1. Membuat desain Fasilitas pengaduk pakan ternak sapi .

2. Membandingkan beban torsi operator fasilitas lama dengan fasilitas baru hasil perancangan.

3. Membandingkan waktu baku dan output standart fasilitas lama dengan waktu baku dan output standart fasilitas baru.

\section{TINJAUAN PUSTAKA DAN METODOLOGI \\ Pengertian Ergonomi}

Ergonomi atau Ergonomics

(bahasa Inggrisnya) sebenarnya berasal dari kata Yunani yaitu Ergo yang berarti kerja dan Nomos yang berarti aturan atau hukum. Ergonomi mempunyai berbagai batasan arti, di Indonesia disepakati bahwa ergonomi adalah ilmu serta penerapannya yang berusaha untuk menyerasikan pekerjaan dan lingkungan terhadap orang atau sebaliknya dengan tujuan tercapainya produktifitas dan efisiensi yang setinggi-tingginya melalui pemanfaatan manusia seoptimal-optimalnya (Nurmianto, 2000).

Ergonomi merupakan salah satu dari persyaratan untuk mencapai desain yang qualified, certified, dan customer need. Ilmu ini akan menjadi suatu keterkaitan yang simultan dan menciptakan sinergi dalam pemunculan gagasan, proses desain, dan desain final.

Ergonomi merupakan ilmu perancangan berbasis manusia (Human Centered Design). Dengan diterapkannya ergonomi, sistem kerja menjadi lebih produktif dan efisien. Menurut (Sutalaksana 1979), dilihat dari sisi rekayasa, informasi hasil penelitian Ergonomi dapat dikelompokkan dalam 4 bidang penelitian, yaitu:

1. Penelitian tentang Display. Display adalah alat yang menyajikan informasi tentang lingkungan yang dikomunikasikan dalam bentuk tanda-tanda atau lambang-lambang. Display terbagi menjadi 2 bagian, yaitu Display Statis dan Display Dinamis. Display Statis adalah display yang memberikan informasi tanpa dipengaruhi oleh variabel waktu, misalnya peta. Sedangkan Display Dinamis adalah display yang dipengaruhi oleh variabel waktu, misalnya spidometer yang memberikan informasi kecepatan kendaraan bermotor dalam setiap kondisi.

2. Penelitian tentang Kekuatan Fisik Manusia. Penelitian ini mencakup mengukur kekuatan/daya fisik manusia ketika bekerja dan mempelajari bagaimana cara kerja serta peralatan harus dirancang agar sesuai dengan kemampuan fisik manusia ketika melakukan aktivitas tersebut. Penelitian ini merupakan bagian dari biomekanik.

3. Penelitian tentang Ukuran/Dimensi dari Tempat Kerja. Penelitian ini diarahkan untuk mendapatkan ukuran tempat kerja yang sesuai dengan ukuran tubuh manusia, dipelajari dalam Antropometri.

4. Penelitian tentang Lingkungan Fisik. Penelitian ini berkenaan dengan perancangan kondisi lingkungan fisik dari ruangan dan fasilitasfasilitas dimana manusia bekerja. Hal ini meliputi perancangan cahaya, suara, warna, temperatur, kelembaban, bau-bauan dan getaran pada suatu fasilitas kerja. 
Sanny Andjar Sari, Dayal Gustopo, Desain Fasilitas Pengaduk Pakan Ternak Untuk Peningkatan Produksi Susu

Dari pengertian-pengertian di atas, disimpulkan bahwa tujuan penerapan ergonomi adalah sebagai berikut:

- Meningkatkan kesejahteraan fisik dan mental, dengan meniadakan beban kerja tambahan (fisik dan mental).

- Mencegah penyakit yang mungkin timbul akibat kerja berat, dan meningkatkan kepuasan kerja.

- Meningkatkan kesejahteraan sosial dengan jalan meningkatkan kualitas kontak sesama pekerja, pengorganisasian yang lebih baik dan menghidupkan sistem kebersamaan dalam tempat kerja.

- Berkontribusi di dalam keseimbangan rasional antara aspek-aspek teknik, ekonomi, antropologi dan budaya dari sistem manusia-mesin untuk tujuan meningkatan efisiensi sistem manusiamesin.

\section{Antropometri}

Antropometri adalah suatu cabang ilmu pengetahuan yang secara khusus mempelajari ukuran tubuh manusia digunakan untuk menentukan perbedaan individu atau kelompok. Antropometri hanya dipandang sebagai suatu pengukuran tubuh manusia semata, maka hal tersebut dapat dilakukan dengan mudah dan sederhana. Namun pada kenyataannya banyak didapati berbagai faktor atau kesulitan yang terlibat, salah satunya ukuran tubuh manusia yang beragam tergantung umur, jenis kelamin, suku bangsa dan kelompok pekerjaan.

Data antropometri yang diperoleh akan diaplikasikan secara luas antara lain dalam hal:

1. Perancangan area kerja

2. Perancangan peralatan kerja seperti mesin, equipment, perkakas (tools) dan sebagainya.

3. Perancangan produk-produk konsumtif seperti pakaian, kursi atau meja komputer.

4. Perancangan lingkungan kerja fisik.
Secara umum pengukuran tubuh manusia dikelompokkan menjadi dua bagian yaitu:

1. Dimensi Fungsional (Dimensi Dinamis). Dimensi dinamis adalah pengukuran pada suatu kondisi dimana tubuh pada posisi kerja atau selama pergerakan yang dibutuhkan oleh suatu pekerjaan.

2. Dimensi Struktural (Dimensi Statis). Dimensi struktural adalah pengukuran yang dilakukan pada saat posisi diam (Statis), mencakup kepala, dada, kaki dan lain sebagainya ketika dalam posisi standar.

Di dalam aplikasi data antropometri untuk merancang suatu produk akan ditentukan beberapa permasalahan yang dihadapi, oleh karena itu perlu beberapa saran / rekomendasi ergonomi yang diperhatikan, yaitu:

1. Menetapkan anggota tubuh yang akan difungsikan untuk mengoperasikan alat.

2. Menetapkan dimensi tubuh untuk proses perancangan alat perlu diperhatikan apakah harus menggunakan data struktural body dimention ataukah functional body dimention.

3. Menentukan populasi terbesar yang harus diantisipasi, diakomo-dasikan dan menjadi target utama pemakai rancangan produk tersebut.

4. Menentukan prinsip ukuran yang harus diikuti, misalnya apakah rancangan tersebut untuk ukuran individual yang ekstrim, rentang ukuran yang fleksibel (Adjustable) ataukah ukuran rata-rata.

5. Memilih dari prosentase populasi yang diikuti yaitu 5\%, 50\%, 95\% atau nilai percentile yang lain.

Untuk setiap dimensi tubuh yang telah diidentifikasi kemudian dipilih atau 
Vol. 2, No. 1, Oktober 2014

ditetapkan ukurannya dari data table antropometri yang sesuai.

Salah satu hal yang terpenting dalam perancangan suatu benda produk pada bidang kerja (Work Space) adalah memasukkan batasan-batasan dimensi dari bidang kerja (Work Spae Envelope).

\section{METODOLOGI PENELITIAN}

1. Survey Data Lapangan Mencari permasalahan yang terjadi pada proses pengadukan pakan ternak sapi secara manual.

2. Pengumpulan Data Pengumpulan data yang diperlukan sebagai penunjang yaitu:

- Data proses pengadukan pakan secara manual yang diteliti

- Data Antropometri

3. Pengolahan Data

Melakukan pengolahan data melalui study literatur untuk mendapatkan metode yang tepat, guna memecahkan masalah, yaitu menentukan ukuran dan desain alat pengaduk pakan ternak sapi yang ergonomis.

4. Pembahasan

5. Membuat Alternatif Desain Fasilitas

6. Penentuan Desain Akhir

7. Kesimpulan

\section{HASIL DAN PEMBAHASAN}

Dalam perancangan fasilitas pengaduk pakan ternak secara ergonomis diperlukan beberapa jenis data antropometri yang diambil dari para pekerja di peternakan sapi perah di Pujon, Batu Malang. Pengukuran dan pertimbangan antropometri yang dilakukan meliputi :

\section{Bentang Tangan}

Aplikasi: Untuk menentukan panjang maksimal dari kerangka alat pengaduk pakan ternak.

Persentil yang digunakan : $P_{5}$ Hasil pengukuran : $=152.25 \mathrm{~cm}$
Pertimbangan : Dengan memakai , maka diharapkan panjang mesin tidak terlalu panjang dan operator yang ukuran tubuhnya terkecil hingga terbesar dapat menjangkau mesin secara mudah.

\section{Tinggi Siku Berdiri}

Aplikasi: Untuk menentukan tinggi maksimum drum tempat pemrosesan (pengadukan).

Persentil yang digunakan :

Hasil pengukuran : $=102.75 \mathrm{~cm}$

Pertimbangan : Dengan memakai hasil pengukuran , diharapkan operator yang ukuran tubuhnya kecil dalam menjangkau tidak terlalu tinggi dan operator yang ukuran tubuhnya besar tidak terlalu rendah.

\section{Jangkauan Lengan Ke Samping}

Aplikasi : Untuk menentukan jarak jangkauan operator dengan saklar (dengan posisi tangan kanan diagonal ke bawah).

Persentil yang digunakan :

Hasil pengukuran : $=60 \mathrm{~cm}$

Pertimbangan : Dengan memakai hasil pengukuran , diharapkan operator yang ukuran tubuhnya besar dalam menjangkau tidak terlalu rendah (tidak terlalu membungkuk saat menghidupkan dan mematikan mesin).

Kebutuhan-kebutuhan pengguna dari alat pengaduk pakan ternak adalah ditunjukkan pada tabel 2 sebagai berikut : 
Sanny Andjar Sari, Dayal Gustopo, Desain Fasilitas Pengaduk Pakan Ternak Untuk Peningkatan Produksi Susu

Tabel 2. Kebutuhan Pengguna dari Alat Pengaduk Pakan Ternak

\begin{tabular}{|l|c|l|}
\hline No & Kebutuhan & Uraian \\
\hline 1 & Kenyamanan & $\begin{array}{l}- \text { Ukuran alat pengaduk pakan ternak sesuai dengan tinggi dan } \\
\text { jangkauan tangan pemakainya } \\
- \text { Operator bekerja dengan posisi yang benar } \\
- \text { Mempermudah proses pengadukan pakan ternak }\end{array}$ \\
\hline 2 & Keamanan & $\begin{array}{l}- \text { Tidak membahayakan keselamatan operator saat digunakan } \\
- \text { Bahan yang digunakan dapat menjamin kebersihan dan } \\
\text { kehigienisan hasil pengadukan pakan }\end{array}$ \\
\hline 3 & $\begin{array}{c}\text { Kemudahan } \\
\text { Operasional }\end{array}$ & $\begin{array}{l}- \text { Sistem atau prinsip kerja alat pengaduk pakan ternak mudah } \\
\text { dimengerti } \\
- \text { Kemudahan menghidupkan dan mematikan motor listrik }\end{array}$ \\
\hline 4 & $\begin{array}{c}\text { Peningkatan } \\
\text { atau Hasil } \\
\text { Output } \\
\text { Standart }\end{array}$ & $\begin{array}{l}- \text { Dapat meningkatkan output standart hasil pengadukan pakan } \\
\text { ternak }\end{array}$ \\
& & Dapat mempersingkat waktu kerja pengadukan pakan \\
\hline
\end{tabular}

\section{Spesifikasi Alat Hasil Rancangan}

Spesifikasi alat pengaduk pakan ternak hasil perancangan yaitu merupakan alat pengaduk pakan ternak sistem semi otomatis, dengan sumber tenaga yang digunakan yaitu motor listrik.

Tabel 3. Komponen Utama Alat Pengaduk Pakan Ternak

\begin{tabular}{|c|c|c|l}
\hline No & $\begin{array}{c}\text { Nama } \\
\text { Komponen }\end{array}$ & Bahan & \multicolumn{1}{|c}{ Fungsi } \\
\hline 1 & Motor Listrik & Lilitan tembaga & $\begin{array}{l}\text { Mengubah energi listrik menjadi } \\
\text { energi penggerak (dengan memutar } \\
\text { rotor) }\end{array}$ \\
\hline 2 & Tanki (drum) & Plat besi & $\begin{array}{l}\text { Wadah untuk mengaduk pakan yang } \\
\text { akan dicampur }\end{array}$ \\
\hline 3 & Support & Besi siku & Penyangga seluruh komponen \\
\hline 4 & Shaft Tangki & Silinder Pedal & Sebagai penahan tangki \\
\hline 5 & Pulley & Besi / tembaga & $\begin{array}{l}\text { Mereduksi putaran motor terhadap } \\
\text { putaran shaft }\end{array}$ \\
\hline
\end{tabular}

Tabel 4. Komponen Sekunder Alat Pengaduk Pakan Ternak

\begin{tabular}{|c|c|c|c|}
\hline No & Nama Komponen & Bahan & Fungsi \\
\hline 1 & Bearing & Baja & Penumpu As untuk berputar \\
\hline 2 & $\begin{array}{c}\text { Pillow } \\
\text { block/Bantalan }\end{array}$ & $\begin{array}{c}\text { Bola } \\
\text { Perunggu }\end{array}$ & Penumpu As tetapi tidak pada satu kaki \\
\hline 3 & Mur dan Baut & SC41 & $\begin{array}{c}\text { Sebagai pengikat komponen pada alat } \\
\text { pengaduk pakan ternak. }\end{array}$ \\
\hline 4 & V-belt & Karet streng & Penghubung Pulley \\
\hline 5 & Saklar Box & Plastik & $\begin{array}{c}\text { Sebagai tombol power (On/Off) dari } \\
\text { motor listrik }\end{array}$ \\
\hline
\end{tabular}


Cara kerja dari pengaduk pakan ternak adalah

- Pertama menyalakan motor melalui handle on / off

- Kemudian bahan (dedak, kulit kopi, polar, bungkil,garam) dimasukkan menjadi satu ke dalam mesin dengan takaran yang sudah disiapkan melalui corong pemasukan material secara terus menerus sesuai takaran

- Setelah itu meletakkan karung di tempat output sebagai tempat penampungan seluruh bahan yang sudah tercampur

- Selanjutnya pakan ternak dikemas ke dalam karung

- Pakan siap diantarkan ke kandangkandang ternak

\section{Kriteria Desain}

Berdasarkan analisa data maka konsep yang dijadikan acuan untuk mendesain alat pengaduk pakan ternak adalah :

1. Mekanisme mudah

Alat ini cara pengoperasiannya harus mudah dipahami oleh operator meskipun berbeda latar pendidikannya.

2. Perawatan mudah

Alat yang dirancang mudah dalam hal perawatannya karena bahan yang digunakan merupakan bahan yang mudah dibersihkan serta sistem yang digunakan memungkinkan alat tersebut dalam keadaan bersih

3. Kualitas terjamin

Daya tahan atau kekuatan dari alat pengaduk pakan ternak dapat dipertanggungjawabkan karena dari bahan yang kuat.

4. Bentuk menarik

Mempunyai bentuk yang memungkinkan operator dapat menginspeksi alat sehingga produktifitas dapat meningkat.

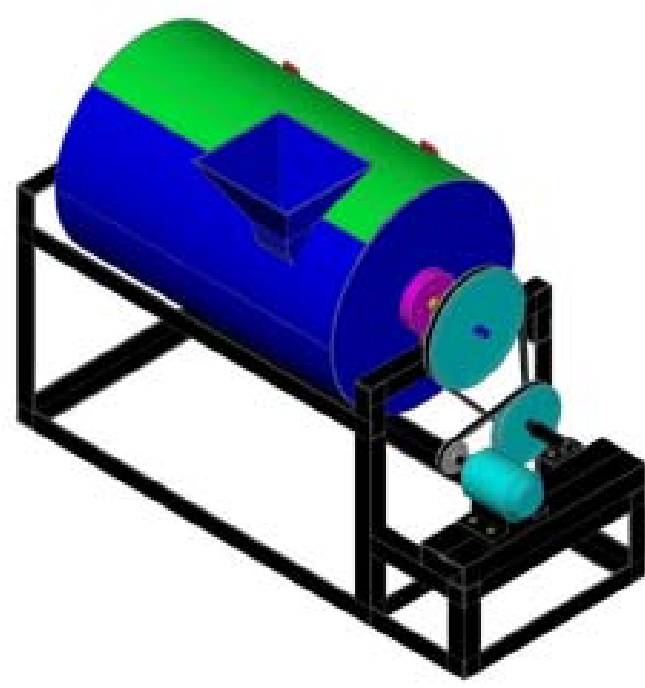

Gambar 1. Final Desain

\section{KESIMPULAN}

Dimensi mesin pengaduk pakan ternak telah sesuai dengan batas yang ditentukan dari perhitungan data antropometri, yaitu :

\section{- Bentang Tangan}

Persentil yang digunakan adalah $P_{5}=$ $152.25 \mathrm{~cm}$ untuk menentukan panjang maksimal alat. Pengukuran pada alat hasil perancangan menunjukkan panjang alat adalah $143 \mathrm{~cm}$.

\section{- Tinggi Siku}

Persentil yang digunakan adalah $P_{50}=$ $102.75 \mathrm{~cm}$ untuk menentukan tinggi maksimal dari penempatan drum pengadukan. Pengukuran pada alat hasil perancangan menunjukkan penempatan drum adalah $99 \mathrm{~cm}$ dari permukaan alas kerangka.

- Jangkauan Lengan ke Samping Persentil yang digunakan adalah $=60 \mathrm{~cm}$ untuk menentukan jarak maksimal dari posisi pekerja berdiri di posisi memasukkan material sampai ke tempat peletakan saklar. Pengukuran jarak tersebut pada alat hasil perancangan adalah $50 \mathrm{~cm}$. 
Sanny Andjar Sari, Dayal Gustopo, Desain Fasilitas Pengaduk Pakan Ternak Untuk Peningkatan Produksi Susu

Alat Pengaduk Pakan Ternak Hasil Rancangan Berdasarkan Torsi Operator.

- Pada sikap kerja operator, mengalami penurunan beban yang diterima oleh punggung dari alat lama sebesar $84 \mathrm{Nm}$ menjadi $17 \mathrm{Nm}$ dengan alat baru.

- Pada sikap kerja operator, mengalami penurunan beban yang diterima oleh leher dari alat lama sebesar $7 \mathrm{Nm}$ menjadi $4 \mathrm{Nm}$ dengan alat baru.

Alat Pengaduk Pakan Ternak Hasil Rancangan Berdasarkan Perhitungan Waktu Baku dan Output Standart.
- Penurunan waktu baku sebesar 0.17 menit/ kg, yaitu :

- Sebelum perancangan alat : 0.25 menit/ $\mathrm{kg}$

- Sesudah perancangan alat : 0.08 menit/ $\mathrm{kg}$

- Peningkatan output standart sebesar 8.5 $\mathrm{kg} /$ menit. dengan prosentase $212.5 \%$, yaitu :

Sebelum perancangan alat : $4 \mathrm{~kg} /$ menit.

Sesudah perancangan alat : $12.5 \mathrm{~kg} /$ menit

Prosentase kenaikan Output Standart

$$
\begin{aligned}
& =\frac{\text { Os baru-Os lama }}{\text { Os lama }} \times 100 \% \\
& =\frac{12.5-4}{4} \times 100 \% \\
& =2.125 \times 100 \% \\
& =212.5 \%
\end{aligned}
$$




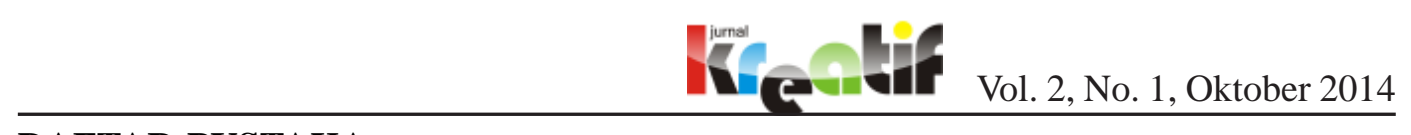

DAFTAR PUSTAKA :

Nurmianto, Eko. 2000.Ergonomi Konsep Dasar dan Aplikasinya. Penerbit PT.Guna Widya.Surabaya.

Sritomo, Wignyosoebroto. 2003. Ergonomi Studi Gerak dan Waktu. Penerbit Guna Widya.Surabaya. 